\title{
PENGELOLAAN PENDIDIKAN KARAKTER DISIPLIN ANAK USIA DINI STUDI KASUS DI AL-MUNA ISLAMIC PRESCHOOL SEMARANG
}

\author{
A.Tabi'in \\ Institut Agama Islam Negeri (IAIN) Pekalongan \\ E-mail: ahmadtabiin6@gmail.com
}

Article received: 16 November 2016 Review process: 03 Februari 2017

Article published: 28 Februari 2017

\begin{abstract}
Abstrak
Pendidikan karakter pada anak usia dini dewasa ini sangat diperlukan dikarenakan saat ini Bangsa Indonesia sedang mengalami krisis karakter dalam diri anak bangsa. Karakter disini adalah watak, tabiat, atau kepribadian seseorang yang terbentuk dari hasil internalisasi berbagai kebajikan yang diyakini dan digunakan sebagai landasan untuk cara pandang, berpikir, bersikap dan bertindak. Membangun karakter terhadap anak merupakan tindakan menjadikan seorang anak terbiasa untuk berperilaku baik, sehingga ia menjadi terbiasa. Penelitian ini bertujuan untuk mengetahui bagaimana pendidikan karakter disiplin yang telah berjalan selama ini, baik dari segi perencanaannya, proses pembelajaran, penilaian dan faktor pendukung serta penghambat dalam pendidikan karakter disiplin anak usia dini.

Penelitian ini menggunakan pendekatan penelitian kualitatif dengan strategi penelitian studi kasus. Penelitian ini dilakukan di Al-Muna Islamic Preschool Semarang. Metode pengumpulan data dilakukan dengan cara wawancara, observasi dan dokumentasi. Proses analisis data meliputi reduksi data, data display dan penarikan kesimpulan.

Hasil penelitian menunjukkan bahwa (1) pengelolaan pendidikan karakter disiplin anak usia dini dimulai dari perencanaan pembelajaran dengan baik, perencanaan pembelajaran karakter disiplin terintegrasi dengan pembelajaran yang ada dengan cara mengintegrasikan pendidikan karakter disiplin dalam perencanaan pembelajaran dalam bentuk RKM dan RKH (2) Proses pembelajaran karakter disiplin dilaksanakan setiap hari secara terintegrasi dengan pembelajaran yang sudah dijadwalkan dengan masing-masing bagian pokok bahasan disesuaikan dengan tema. (3) Penilaian yang di gunakan dalam pendidikan karakter disiplin anak di Al-Muna Islamic Preschool menggunakan catatan anekdot, observasi dan catatan harian. (4) Faktor pendukung dan penghambat dalam menerapkan pendidikan karakter disiplin yaitu guru menjadi teladan bagi siswa serta adanya tata aturan yang jelas. Faktor penghambat yaitu, Penerapan pendidikan karakter disiplin anak yang tidak konsisten.

Saran dalam penelitian ini adalah (1)perencanaan pendidikan karakter disiplin anak perlu dikembangkan secara lebih sistematis dan terperinci. (2) proses pendidikan karakter disiplin anak harus konsisten dimasing-masing sentra pembelajaran. (3) Penilaian pendidikan karakter disiplin anak perlu ditinjau kembali dan diselaraskan dengan penilaian yang disarankan oleh Puskur Kemendiknas 2011. 4) Guru sebagai model utama dalam memberikan contoh kepada anak didik mengenai kedisiplinan, disertai dengan contoh riil/langsung tentang kedisiplinan di sekolah.
\end{abstract}

Kata Kunci: Pendidikan Karakter, Disiplin, Anak Usia Dini. 


\section{A. PENDAHULUAN}

Pendidikan adalah salah satu bentuk perwujudan kebudayaan manusia, yang dinamis dan sarat perkembangan. Perkembangan pendidikan merupakan hal yang seharusnya terjadi, sejalan dengan perubahan budaya kehidupan. Perubahan budaya kehidupan sejalan dengan, perubahan perkembangan ilmu dan teknologi sekarang ini, dimana perubahan ini memberikan dampak yang sangat luas disegala aspek kehidupan.

Krisis multi dimensi yang dialami bangsa Indonesia saat ini telah memberi dampak yang besar dalam berbagai tatanan kehidupan bangsa. Banyak yang mengatakan bahwa masalah terbesar yang dihadapi bangsa Indonesia adalah terletak pada aspek moral. Terbukti dengan banyaknya berita tentang tawuran antar pelajar dan kasus-kasus narkoba, anak bolos sekolah yang sering kita lihat di televisi. Tidak jarang pemakai narkoba masih menyandang status pelajar, beberapa pelajar berada di "terali besi" karena menganiaya gurunya sendiri, anak yang tidak lagi memiliki sopan santun pada orang tua. Kondisi tersebut memerlukan perhatian dan pemikiran guna menemukan solusinya secara tepat agar bangsa Indonesia bisa bangkit.

Persoalan tawuran antar siswa mengindikasikan bahwa kebijakan pendidikan karakter yang dibuat pemerintah belum terealisasi sebagaimana yang diharapkan. Jangankan persoalan tawuran antar siswa serta kedisiplinan siswa di sekolah, masalah-masalah seperti bolos, menyontek, sering terlambat ke sekolah, tidak mengerjakan tugas, pornografi, pembangkangan, narkoba dan miras telah sangat merisaukan banyak pihak. Berhadapan dengan pelbagai persoalan siswa di atas, maka pendidikan karakter disiplin anak menjadi semakin urgen. Karena itulah menarik untuk mempertanyakan dan menelusuri sejauh mana sekolah sebagai lembaga pendidikan formal menjalankan perannya mengimplementasikan kebijakan pendidikan karakter disiplin pada anak usia dini dan Bagaimana mengelola atau me-manage pendidikan karakter di lingkungan sekolah.

Berbagai permasalahan ada di atas yang melanda bangsa belakangan ini ditengarai karena jauhnya kita dari karakter. Jati diri bangsa seolah tercabut dari akar yang sesungguhnya. Sehingga pendidikan karakter menjadi topik yang hangat dibicarakan belakangan ini, dan digalakkan untuk diterapkan dalam semua aspek pendidikan lebih utamanya pendidikan pada anak usia dini. Pembentukan karakter merupakan salah satu tujuan pendidikan nasional. Pasal I UU Sisdiknas tahun 2003 menyatakan bahwa diantara tujuan pendidikan nasional adalah mengembangkan potensi peserta didik untuk memiliki kecerdasan, kepribadian dan akhlak 
mulia. Amanah UU Sisdiknas tahun 2003 itu bermaksud agar pendidikan tidak hanya membentuk insan Indonesia yang cerdas, namun juga berkepribadian atau berkarakter, sehingga nantinya akan lahir generasi bangsa yang tumbuh berkembang dengan karakter yang bernafas nilai-nilai luhur bangsa serta agama.

Mendasarkan pada salah satu tujuan pendidikan dasar yaitu membentuk karakter siswa, maka perlu dikembangkan pendidikan karakter disiplin yang mengarah pada pembentukan perilaku yang unggul. Karakter disiplin anak memberikan landasan kokoh bagi siswa untuk mengembangkan dan menemukan jati diri siswa, baik dalam melanjutkan studi pada jenjang lebih lanjut maupun mengarungi kehidupan (Megawangi, 2007: 14).

Diharapkan melalui pengembangan pendidikan karakter disiplin anak memahami potensi yang dimilikinya, siswa juga akan memiliki karakter unggul seperti karakter kedisiplinan. Pemahaman yang baik akan kekuatan dan potensi yang dimiliki akan memunculkan sikap dan perilaku mandiri. Karakter disiplin inilah yang kelak akan sangat mendukung siswa dalam mengarungi kehidupan dan menata masa depan.

Pendidikan karakter disiplin anak usia dini di Al-Muna Islamic Preschool Semarang sangat unik dan menarik ketika diteliti lebih lanjut dikarenakan di Al-Muna Islamic Preschool Semarang menerapkan Model "Pendidikan Holistik Berbasis Karakter" (Character-based Holistic Education) khususnya pada aspek karakter disiplin anak usia dini. Kurikulum yang digunakan menggunakan "Kurikulum Holistik Berbasis Karakter" (Character-based Integrated Curriculum), yaitu kurikulum terpadu yang "menyentuh" semua aspek kebutuhan anak, yang bertujuan untuk mengembangkan seluruh dimensi manusia. Sesuai dengan prinsip pendidikan holistik, manusia yang berkarakter adalah manusia yang berkembang seluruh dimensinya secara utuh (holistik), sehingga manusia tersebut bisa disebut holy (suci dan bijak). Akar kata holy, adalah whole (menyeluruh), sehingga arti holy man adalah manusia yang berkembang secara utuh dan seimbang seluruh dimensinya.

Al-Muna Islamic Preschool Semarang dalam menerapkan pendidikan karakter disiplin anak usia dini selain menggunakan metode Holsitik Berbasis karakter juga mengolaborasikan dengan metode-metode pendidikan yang menunjang pendidikan karakter tersebut, misalnya Brain-based Learning, Contextual Learning, Cooperative Learning, Inquiry-based Learning, Developmentally Appropriate Practices, dsb, dimana para gurunya dibekali training untuk menguasai metode-metode tersebut secara praktis. 


\section{B. Metode penilaian}

Penelitian ini merupakan penelitian kualitatif ( field research) yang pada hakikatnya merupakan metode untuk menemukan secara spesifik dan realistis tentang apa yang sedang terjadi pada suatu tempat terjadinya gejala yang diselidiki (Mardalis, 2004: 24). Data-data yang terkait dengan penelitian ini dikumpulkan melalui studi lapangan.

Mengingat studi ini adalah untuk mengetahui bagaimana pengelolaan pendidikan karakter disiplin anak di Al-Muna Islamic Preschool Semarang, maka secara metodologis penelitian ini dalam kategori penelitian kualitatif, yaitu prosedur penelitian yang menghasilkan data deskriptif berupa kata-kata tertulis atau lisan dari orang-orang dan perilaku yang dapat diamati. Data yang diperoleh berupa kata-kata, gambar, perilaku yang dituangkan bukan dalam bentuk perhitungan statistik. Dalam pengumpulan data, peneliti menggunakan beberapa teknik, diantaranya: (1) Wawancara, metode ini digunakan untuk mencari data dengan pihak-pihak yang terkait, guna mengetahui bagaimana pelaksanaan pembelajaran di Al-Muna Islamic Preschool Semarang. (2) Observasi, tujuan dari kegiatan observasi ini adalah untuk mendeskripsikan setting kegiatan yang sedang terjadi, orang yang terlibat didalam kegiatan tersebut, waktu, kegiatan dan makna yang diberikan oleh pelaku yang diamati tentang peristiwa yang bersangkutan. Observasi ini dapat dilakukan secara langsung maupun tidak langsung. Dalam hal ini peneliti melakukan observasi langsung mengenai Pengelolaan pendidikan karakter disiplin anak usia dini studi kasus di Al-Muna Islamic Preschool Semarang. (3) Dokumentasi, dokumen merupakan catatan peristiwa lampau. Dokumen bisa berbentuk tulisan, gambar atau karya-karya monumental dari seseorang. Studi dokumen merupakan pelengkap dari penggunaan metode observasi dan wawancara dalam penelitian kualitatif (Sugiyono, 2005:72).

Metode Dokumentasi adalah mencari data mengenai hal-hal atau variabel yang berupa catatan, transkip, buku, surat kabar, majalah, prasasti, notulen rapat, agenda dan sebagainya (Arikunto, 1993:202). Hal ini peneliti menggunakan metode dokumentasi untuk mencari datadata otentik sebagai pelengkap, diantaranya untuk mendapatkan data tentang struktur organisasi, sarana dan prasarana, jumlah guru, karyawan dan siswa, dan sebagian umum data-data yang ada di Al-Muna Islamic Preschool Semarang.

Teknik analisis data merupakan suatu langkah yang sangat kritis dalam penelitian memastikan pola analisis yang mana digunakan sesuai dengan data yang dikumpulkan. Dalam penelitian ini menggunakan model analisis kualitatif. Analisis data dalam sebuah penelitian 
merupakan bagian yang sangat penting karena dengan analisis inilah data yang ada akan nampak manfaatnya terutama dalam memecahkan masalah penelitian dan mencapai tujuan akhir dalam penelitian.

Ada tiga komponen utama dalam proses analisis data yaitu: (1) Data reduction (Reduksi Data), Proses reduksi data berlangsung terus sepanjang penelitian. Bahkan prosesnya sudah dimulai sebelum pelaksanaan pengumpulan data, seperti sejak penelitian memutuskan tentang kerangka kerja konseptual, pemilihan kasus, menyusun pertanyaan penelitian dan juga waktu menentukan cara pengumpulan data yang akan digunakan (Milles dan Huberman, 1992:16). Pada waktu pengumpulan data berlangsung, reduksi data dilakukan dengan membuat ringkasan dari catatan di lapangan, dibuat rangkuman, memusatkan tema, menentukan batas - batas permasalahan dan menulis memo. Dengan reduksi data berarti mempertegas, meringkas, membuat fokus, menyeleksi dan membuang hal - hal yang tidak penting serta mengatur data secara runtut, sehingga mempermudah simpulan penelitian. (2) Data display (Sajian Data), Data dalam penelitian ini disajikan terutama dalam bentuk narasi kalimat yang disusun secara logis dan sistematis mengacu pada rumusan masalah, artinya sajian data ini merupakan gambaran data hasil penelitian untuk menjawab permasalahan berdasarkan logika penelitian, disamping itu penyajian data dilakukan dalam bentuk gambar atau skema untuk mendukung keutuhan narasi, sehingga merupakan sajian data yang lengkap. (3) Conclusion drawing/Verification (Verifikasi Data atau Penarikan Kesimpulan), Dalam penelitian biasanya dijumpai berbagai hal yang harus dipahami artinya seperti peraturan, pola-pola, pernyataan, konfigurasi yang mungkin, alasan sebab akibat dan berbagai proposisi (Milles dan Huberman,1992:17). Hal - hal tersebut sebagai dasar konfesi awal yang sifatnya masih terbuka, karena bisa jadi masih kurang jelas, akan tetapi kemudian berangsur-angsur semakin meningkat dengan landasan yang kuat. (Milles dan Hubberman, 1992:16).

\section{HASIL DAN PEMBAHASAN}

\section{a. Perencanaan Pendidikan Karakter Disiplin Anak Usia Dini di Al-Muna Islamic Preschool}

Perencanaan pada dasarnya merupakan suatu proses memikirkan dan menetapkan secara matang arah, tujuan dan tindakan sekaligus mengkaji berbagai sumber daya dan metode yang tepat. Pengertian serupa dikemukakan oleh Gibson (dalam Sagala, 2010:56), “ perencanaan mencakup kegiatan menentukan sasaran dan alat sesuai untuk mencapai tujuan yang telah 
ditentukan ". Perencanaan yang dibuat secara matang akan berfungsi sebagai kompas untuk mencapai tujuan organisasi. Untuk itu Sergiovanni (dalam Sagala, 2010: 57) menegaskan: "plans are guides, approximation, goal post, and compass setting not irrevocable commitments or dicision commandments”. “ Rencana adalah pembimbing, pengira-ngira, hasil akhir sebagai pengatur ataupun petunjuk agar tidak bisa dirubah komitmen atau keputusan mengenai aturanaturan yang penting.

Pada hakikatnya sebelum pelaksanaan pembelajaran dimulai, dibutuhkan adanya persiapan atau perencanaan pembelajaran terlebih dahulu. Persiapan merupakan perencanaan jangka pendek untuk memperkirakan atau memproyeksikan tentang apa yang dilakukan. Dengan demikian, makna persiapan mengajar berarti upaya merencanakan sesuatu dalam waktu jangka pendek untuk memperkirakan tindakan apa yang akan dilakukan dalam kegiatan pembelajaran, terutama berkaitan dengan pembentukan kompetensi. Dalam dunia pembelajaran banyak sekali dijumpai berbagai macam konsep pembelajaran yang dipakai dalam pengembangan pembelajaran di sekolah.

\section{Konsep perencanaan karakter disiplin anak usia dini di AL-Muna Islamic Preschool}

Berikut ini adalah gambar konsep perencanaan pendidikan karakter disiplin anak di AlMuna Islamic Preschool, yang meliputi perencanaan tahunan, perencanaan semester, perencanaan mingguan, perencanaan harian dan bahan ajar.

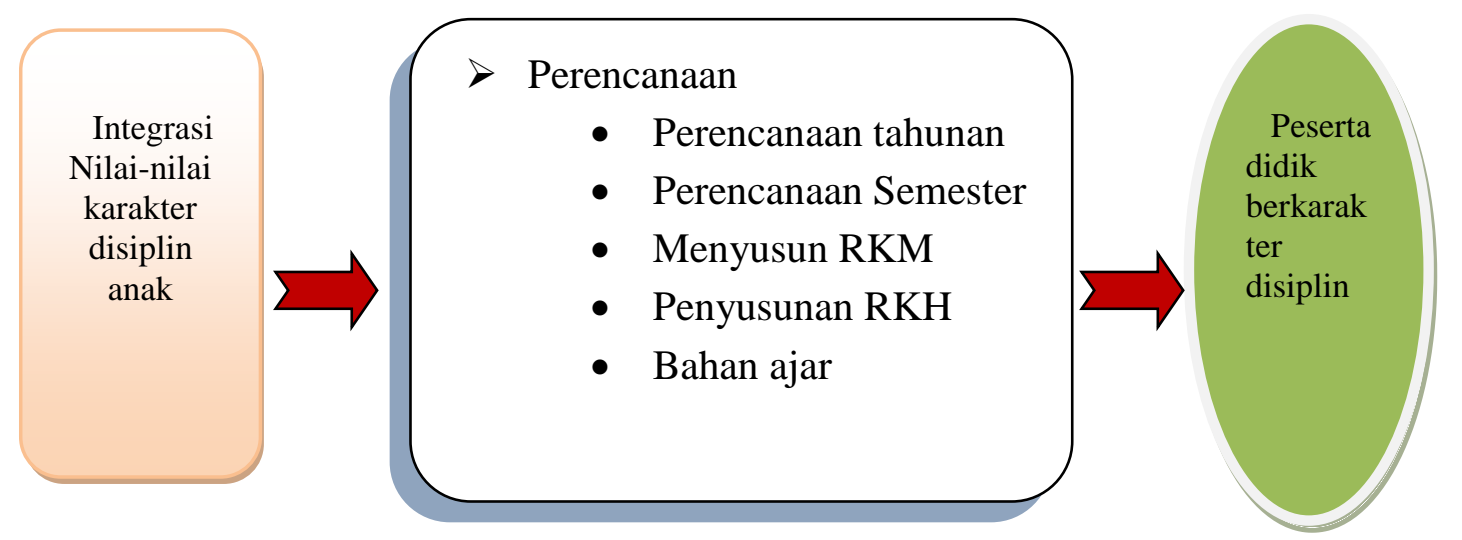

Gambar 1 Skema Perencanaan Pendidikan Karakter Disiplin.

Bentuk-bentuk perencanaan dalam proses pembelajaran pendidikan karakter disiplin di Al-Muna Islamic Preschool : a) Perencanaan Tahunan. b) Perencanaan Semester. c) 
Perencanaan Mingguan. (Rencana Kegiatan Mingguan). d) Perencanaan Harian (Rencana Kegiatan Harian).

Hal tersebut menjadi salah satu tugas profesional seorang guru. dalam membuat perencanaan pembelajaran sangat disesuaikan dengan tema yang akan dibahas, agar tercipta sebuah kesatuan pembelajaran yang lebih integral atau tidak terputus. Guru membuat program tahunan kemudian dikembangkan menjadi program semester serta dituangkan dalam satuan kegiatan mingguan (RKM), kemudian dari RKM itu membuat satuan kegiatan harian (RKH) yang akan diterapkan dalam kegiatan harian yang acuannya berbasis karakter dan muatannya terdiri dari akhlak dan motorik.

Perencanaan adalah proses yang sistematis dalam pengambilan keputusan tentang tindakan yang akan dilakukan pada waktu yang akan datang. Perencanaan pembelajaran tersebut bermuara pada komponen yang membentuk sistem proses pembelajaran. Komponen sistem proses pembelajaran ini sebagaimana dikemukakan Sanjaya (2008:58) meliputi tujuan, materi, metode, media, dan penilaian. Keseluruhan rancangan komponen pembelajaran tersebut dapat dituangkan dalam bentuk Silabus, perencanaan tahunan, perencanaan semester, RKM dan RKH yang dilengkapi dengan Bahan Ajar yang sesuai. Salah satu kemampuan yang harus dimiliki oleh guru adalah membuat perencanaan secara profesional dalam melaksanakan tugas dan tanggung jawabnya sebagai seorang pendidik, pembelajar, sekaligus sebagai perancang pembelajaran.

Inti dari perencanaan pembelajaran adalah proses memilih, menetapkan dan mengembangkan, pendekatan, metode, dan teknik pembelajaran, menawarkan bahan ajar, menyediakan pengalaman belajar yang bermakna, serta mengukur tingkat keberhasilan proses pembelajaran dalam mencapai hasil pembelajaran.

Perencanaan pembelajaran yang terintegrasi dengan pendidikan karakter merupakan "hal baru" yang dilakukan oleh guru. Dikatakan demikian, karena sebagian guru merasa aneh dan kesulitan dalam membuat perencanaan pembelajaran yang terintegrasi. Hal ini terjadi karena guru yang bersangkutan belum memahami sepenuhnya tentang hubungan pembelajaran dengan efektifitas kegiatan belajar mengajar. Disamping itu, sebagian guru juga memiliki persepsi dan pandangan yang berbeda tentang perencanaan pembelajaran. Disatu sisi, perencanaan pembelajaran membantu guru untuk mempermudah dalam proses pelaksanaan kegiatan belajar mengajar, namun disisi lain, penyusunan perencanaan pembelajaran yang rumit dan melelahkan 
menjadikan guru agak malas untuk membuatnya. Ini yang menjadikan ada sebagian guru ada yang mengusulkan agar kewajiban untuk membuat perencanaan pembelajaran dihapuskan saja. Dalam pandangan mereka, sebaiknya guru dituntut untuk mengadopsi saja perencanaan pembelajaran dengan situasi dan kondisi tempat mereka mengajar. Hal inilah yang akan memperingan beban tugas guru dalam kegiatan belajar mengajar.

\section{Aspek yang Harus Diperhatikan Guru dalam Penyusunan Perencanaan Pendidikan}

\section{Karakter Disiplin Anak}

Kesuksesan suatu lembaga pendidikan dipengaruhi oleh kualitas gurunya. Jika lembaga pendidikan tersebut dipenuhi dengan guru yang berkualitas, maka output yang dihasilkan pun akan lebih terjamin dan maksimal. Begitu pula sebaliknya, jika lembaga pendidikan tersebut banyak dihuni oleh guru yang kualitasnya jauh dari unsur kemutuan, maka output yang dikeluarkannya menjadi kurang maksimal dan bisa jadi malah tidak bisa menyamai standar pembelajaran yang diharapkan.

Berikut ini aspek yang harus diperhatikan guru dalam perencanaan pendidikan karakter disiplin, yang harus dipahami oleh tenaga pendidik PAUD :

a. Sesuai Dengan Tahap Perkembangan Anak

Rencana pembelajaran disusun untuk memberikan panduan dalam menyiapkan kegiatan pembelajaran yang sesuai dengan kemampuan anak. Dengan kata lain penyusunan rencana pembelajaran harus disesuaikan dengan tahap perkembangan anak. Rencana pembelajaran yang tidak sesuai dengan tahap perkembangan anak tidak atau kurang memberi manfaat bagi pengembangan kemampuan anak. Sebagai contoh untuk kelompok anak usia 2 tahun yang sudah dapat berjalan dengan lancar, rencana pembelajaran yang berisi latihan berdiri tentunya tidak menantang anak untuk berkembang lebih lanjut. Sebaliknya untuk kelompok anak tersebut yang belum mengenal warna, kegiatan untuk membuat pola warna tidak akan dapat dicapai anak. Mengetahui tahap perkembangan kelompok usia anak dapat merujuk pada Standar Perkembangan.

b. Memenuhi Kebutuhan Belajar Anak

Selain memperhatikan tahap perkembangan anak, rencana pembelajaran juga harus dapat memenuhi kebutuhan belajar anak secara individu karena setiap anak memiliki gaya belajar yang berbeda. Meskipun pada umumnya anak pada kelompok usia tertentu ada dalam tahap perkembangan yang sama, tetapi pada kenyataannya setiap anak memiliki kekhasan masing- 
masing. Oleh karena itu dalam menyusun rencana pembelajaran perlu juga memperhatikan kekhasan anak secara individu. Memahami kekhasan dan kebutuhan pembelajaran masingmasing anak dapat dilakukan melalui Deteksi Dini Tumbuh Kembang (DDTK) di saat anak baru masuk program, atau dengan cara mengamati saat anak main. DDTK adalah sekelompok instrumen yang digunakan untuk mendeteksi tahap perkembangan anak. Apabila perencanaan pembelajaran disusun setelah dilakukan penilaian, maka hasil penilaian perkembangan anak dapat dijadikan dasar untuk membuat perencanaan pembelajaran berikutnya.

c. Menyeluruh (meliputi semua aspek perkembangan)

Rencana pembelajaran yang disusun harus mencakup semua aspek perkembangan anak yang meliputi: moral dan nilai-nilai agama, sosial, emosional, dan kemandirian, bahasa, kognitif, fisik/motorik dan seni sebagai satu kesatuan kegiatan pembelajaran yang menyenangkan. Pada pendidikan anak usia dini pengembangan setiap aspek perkembangan disampaikan dalam kegiatan pembelajaran yang terpadu dengan menggunakan tema. Contoh: dengan tema pembelajaran "Aku", aspek yang dikembangkan mencakup moral dan nilai-nilai agama (mengenal aku sebagai ciptaan Tuhan), bahasa (menambah kosa kata tentang aku, menceritakan keluargaku, dll), kognitif (menghitung jumlah anggota tubuh), sosial emosional (mengenal kesukaan dan ketidaksukaanku), dan seterusnya.

Menanamkan nilai-nilai pendidikan karakter disiplin memerlukan sosok dengan kecakapan keilmuan yang kompleks. Apalagi, pendidikan karakter disiplin sesungguhnya mempunyai kedekatan dengan kehidupan sehari-hari siswa. Proses interaksi antara orang tua dan anak, anak dengan guru, merupakan contoh kehidupan yang didalamnya penuh dengan muatan pendidikan karakter disiplin terutama pada aspek kepatuhan baik di rumah maupun saat di sekolah. Oleh karena itu, dalam melaksanakan kegiatan pembelajaran pendidikan karakter disiplin, apa yang semua yang terjadi, tergelar dan berkembang di masyarakat dan lingkungan sekitar serta lingkungan alam semesta dijadikan sumber belajar, contoh dan teladan (Depdiknas, 2006:

\section{Proses pelaksanaan Pendidikan Karakter Disiplin Anak Usia Dini di Al-Muna Islamic Preschool}

Pembelajaran pada anak usia dini pada hakikatnya adalah pengembangan kurikulum secara konkret berupa seperangkat rencana yang berisi sejumlah pengalaman belajar melalui bermain yang diberikan pada anak usia dini berdasarkan potensi dan tugas perkembangan yang 
harus dikuasainya dalam rangka pencapaian kompetensi yang dimiliki oleh anak (Haling, T.Subhan, 2012: 8).

Proses pembelajaran harus mampu dalam mengembangkan persiapan mengajar, terlebih dahulu perlu menguasai secara teoritis dan praktis unsur-unsur yang terdapat dalam persiapan mengajar. Kemampuan membuat persiapan mengajar merupakan langkah awal yang harus dimiliki guru dan sebagai muara dari segala pengetahuan teori, keterampilan dasar, dan pemahaman yang mendalam tentang objek belajar dan situasi pembelajaran (Agboola Alex. 2012:167).

Adapun pendidikan karakter disiplin di Al-Muna Islamic Preschool ialah dengan cara pengenalan nilai-nilai karakter disiplin kesadaran dan pentingnya nilai-nilai dan penginternalisasian ke dalam tingkah laku peserta didik sehari-hari melalui proses pembelajaran yang baik yang berlangsung didalam maupun di luar kelas. Berikut ini adalah konsep pembelajaran pendidikan karakter.

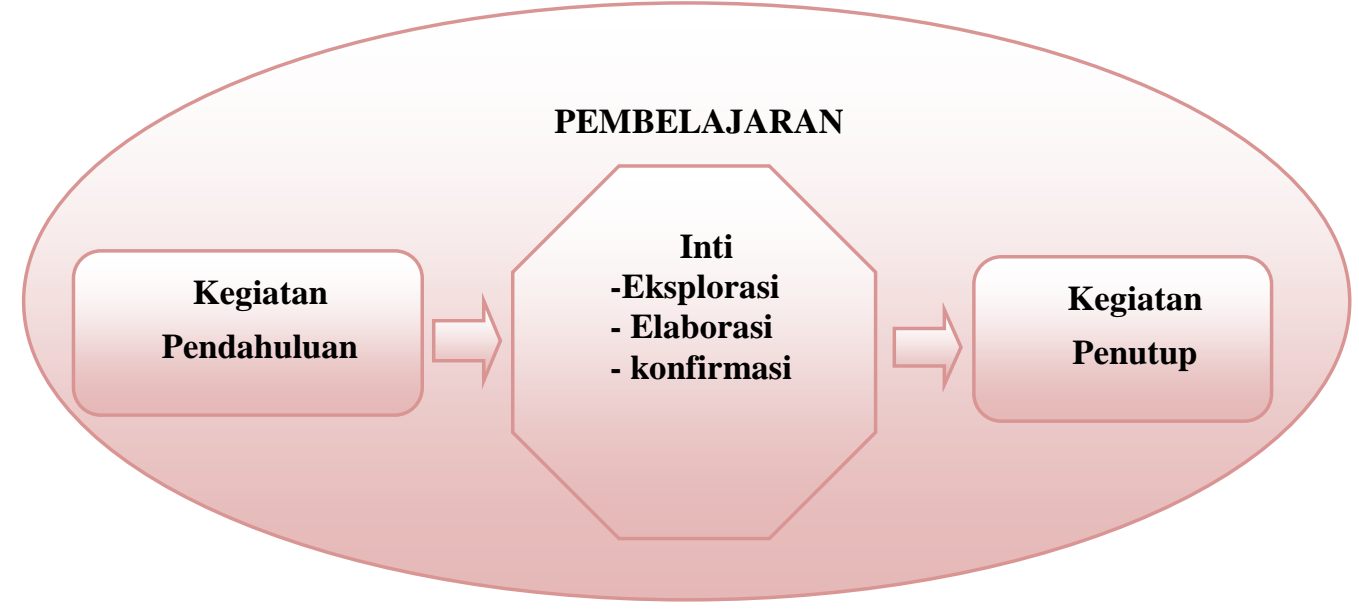

\section{Gambar 2 Proses Pendidikan Karakter Disiplin Anak}

Proses pembelajaran setidaknya harus meliputi Kegiatan awal atau pendahuluan merupakan kegiatan untuk pemanasan dan dilaksanakan secara klasikal. Kegiatan yang dapat dilakukan antara lain : misalnya berdoa/mengucapkan salam, membicarakan tema atau subtema. Kegiatan ini merupakan kegiatan yang dapat mengaktifkan perhatian kemampuan sosial dan emosional anak. Kegiatan ini dapat dicapai melalui kegiatan yang memberi kesempatan kepada anak untuk bereksplorasi dan bereksperimen sehingga dapat memunculkan inisiatif, kemandirian dan kreativitas anak. Serta kegiatan yang dapat meningkatkan pengertian-pengertian, konsentrasi dan mengembangkan kebiasaan bekerja yang baik. 
Kegiatan inti merupakan kegiatan yang dilaksanakan secara individu/kelompok. Istirahat/makan merupakan kegiatan yang digunakan untuk mengisi kemampuan anak yang berkaitan dengan makan : misalnya mengenalkan kesehatan makanan yang bergizi, tata tertib makan yang diawali dengan cuci tangan kemudian makan dan berdoa sebelum makan. Setelah kegiatan makan selesai, anak melakukan kegiatan bermain dengan alat permainan diluar kelas dengan maksud untuk mengembangkan motorik kasar anak dan bersosialisasi. Kegiatan ini sesuai dengan kemauan anak, anak makan kemudian bermain atau sebaliknya anak bermain terlebih dahulu baru setelah itu makan.

\section{Langkah-langkah Pendidikan Karakter Disiplin Anak di Al-Muna Islamic Preschool}

Pendidikan merupakan suatu proses yang kompleks dan melibatkan berbagai aspek yang saling berkaitan. Proses Pembelajaran karakter yang terencana tentunya tidak terlepas dari strategi didalamnya Oleh karena itu, untuk menciptakan pembelajaran karakter disiplin yang baik diperlukan berbagai langkah, diantaranya:

\section{a. Pendahuluan}

Berdasarkan Standar Proses, pada kegiatan pendahuluan, guru: (1) menyiapkan peserta didik secara psikis dan fisik untuk mengikuti proses pembelajaran (2) mengajukan pertanyaanpertanyaan yang mengaitkan pengetahuan sebelumnya dengan materi yang akan dipelajari (3) menjelaskan tujuan pembelajaran atau kompetensi dasar yang akan dicapai; dan (4) menyampaikan cakupan materi dan penjelasan uraian kegiatan sesuai silabus.

Contoh alternatif :

a. Guru datang tepat waktu (contoh nilai yang ditanamkan: disiplin)

b. Guru mengucapkan salam dengan ramah kepada siswa ketika memasuki ruang kelas (contoh nilai yang ditanamkan: santun, peduli)

c. Berdoa sebelum membuka pelajaran (contoh nilai yang ditanamkan: religius)

d. Mengecek kehadiran siswa (contoh nilai yang ditanamkan: disiplin, rajin)

e. Mendoakan siswa yang tidak hadir karena sakit atau karena halangan lainnya (contoh nilai yang ditanamkan: religius, peduli)

f. Memastikan bahwa setiap siswa datang tepat waktu (contoh nilai yang ditanamkan: disiplin) 
g. Menegur siswa yang terlambat dengan sopan (contoh nilai yang ditanamkan: disiplin, santun, peduli)

h. Mengaitkan materi/kompetensi yang akan dipelajari dengan karakter

\section{b. Kegiatan Inti}

Sesuai permen 41 tahun 2007 Pembelajaran melalui 3 tahapan yakni (A) Eksplorasi (peserta didik difasilitasi untuk memperoleh pengetahuan dan keterampilan dan mengembangkan sikap melalui kegiatan pembelajaran yang berpusat pada siswa) (1) Melibatkan peserta didik mencari informasi yang luas dan dalam tentang topik/tema materi yang dipelajari dengan menerapkan prinsip alam jadi guru dan belajar dari aneka sumber (contoh nilai yang ditanamkan: kedisiplinan, mandiri, berfikir logis, kreatif, kerjasama) (2) Menggunakan beragam pendekatan pembelajaran, media pembelajaran, dan sumber belajar lain (contoh nilai yang ditanamkan: kreatif, kerja keras) (3) Memfasilitasi terjadinya interaksi antar peserta didik serta antara peserta didik dengan guru, lingkungan, dan sumber belajar lainnya (contoh nilai yang ditanamkan: kerjasama, saling menghargai, peduli lingkungan) (4) Melibatkan peserta didik secara aktif dalam setiap kegiatan pembelajaran (contoh nilai yang ditanamkan: rasa percaya diri, mandiri) (6) Memfasilitasi peserta didik melakukan percobaan di kelas atau lapangan (contoh nilai yang ditanamkan: mandiri, kerjasama, kerja keras). (B) Elaborasi (peserta didik diberi peluang untuk memperoleh pengetahuan dan keterampilan serta sikap lebih lanjut melalui sumber-sumber dan kegiatan-kegiatan pembelajaran lainnya sehingga pengetahuan, keterampilan, dan sikap peserta didik lebih luas dan dalam). (1) Membiasakan peserta didik untuk membaca yang beragam melalui tugas-tugas tertentu yang bermakna (contoh nilai yang ditanamkan: cinta ilmu, kreatif,logis). (2) Memfasilitasi peserta didik melalui pemberian tugas, dan lain-lain untuk memunculkan gagasan baru baik secara lisan maupun tertulis (contoh nilai yang ditanamkan: kreatif, percaya diri, kritis, saling menghargai, santun) (3) Memberi kesempatan untuk berpikir, menganalisis, menyelesaikan masalah, dan bertindak tanpa rasa takut (contoh nilai yang ditanamkan: kreatif, percaya diri,kritis) (4) Memfasilitasi peserta didik dalam pembelajaran kooperatif dan kolaboratif (contoh nilai yang ditanamkan: kerjasama, saling menghargai, tanggung jawab, disiplin) (5) Memfasilitasi peserta didik berkompetisi secara sehat untuk meningkatkan prestasi belajar (contoh nilai yang ditanamkan: jujur, disiplin, kerja keras, menghargai) (6) Memfasilitasi peserta didik membuat laporan eksplorasi yang dilakukan baik lisan maupun tertulis, secara individual maupun kelompok (contoh nilai yang ditanamkan: jujur, 
bertanggung jawab, percaya diri, saling menghargai, mandiri, kerjasama, disiplin)

Memfasilitasi peserta didik untuk menyajikan hasil kerja individual maupun kelompok (contoh nilai yang ditanamkan: percaya diri, saling menghargai, mandiri, kerjasama) (8) Memfasilitasi peserta didik melakukan pameran, turnamen, festival, serta produk yang dihasilkan (contoh nilai yang ditanamkan: percaya diri, saling menghargai, mandiri, kerjasama) (9) Memfasilitasi peserta didik melakukan kegiatan yang menumbuhkan kebanggaan dan rasa percaya diri peserta didik (contoh nilai yang ditanamkan: percaya diri, saling menghargai, mandiri, kerjasama). (C)

Konfirmasi (peserta didik memperoleh umpan balik atas kebenaran, kelayakan, atau keberterimaan dari pengetahuan, keterampilan, dan sikap yang diperoleh oleh siswa) (1) Memberikan konfirmasi terhadap hasil eksplorasi dan elaborasi peserta didik melalui berbagai sumber (contoh nilai yang ditanamkan: percaya diri, logis, kritis) (2) Memfasilitasi peserta didik melakukan refleksi untuk memperoleh pengalaman belajar yang telah dilakukan (contoh nilai yang ditanamkan: memahami kelebihandan kekurangan) (3) Memberikan umpan balik positif dan penguatan dalam bentuk lisan, tulisan, isyarat, maupun hadiah terhadap keberhasilan peserta didik (contoh nilai yang ditanamkan: saling menghargai, percaya diri, santun, kritis, logis) (4) Memfasilitasi peserta didik untuk lebih jauh/dalam/luas memperoleh pengetahuan, keterampilan, dan sikap, antara lain dengan guru: Berfungsi sebagai narasumber dan fasilitator dalam menjawab pertanyaan peserta didik yang menghadapi kesulitan, dengan menggunakan bahasa yang baku dan benar (contoh nilai yang ditanamkan: peduli, santun); Membantu menyelesaikan masalah (contoh nilai yang ditanamkan: peduli); memberi acuan agar peserta didik dapat melakukan pengecekan hasil eksplorasi (contoh nilai yang ditanamkan: kritis); memberi informasi untuk bereksplorasi lebih jauh (contoh nilai yang ditanamkan: cinta ilmu); dan memberikan motivasi kepada peserta didik yang kurang atau belum berpartisipasi aktif (contoh nilai yang ditanamkan: peduli, percaya diri). (D) Penutup, Dalam kegiatan penutup, guru: (1) Bersama-sama dengan peserta didik dan/atau sendiri membuat rangkuman/simpulan pelajaran (contoh nilai yang ditanamkan: mandiri, kerjasama, kritis, logis); (2) melakukan penilaian dan/atau refleksi terhadap kegiatan yang sudah dilaksanakan secara konsisten dan terprogram (contoh nilai yang ditanamkan: jujur, mengetahui kelebihan dan kekurangan); (3) memberikan umpan balik terhadap proses dan hasil pembelajaran (contoh nilai yang ditanamkan: saling menghargai, percaya diri, santun, kritis, logis); (4) merencanakan kegiatan tindak lanjut dalam bentuk pembelajaran remedi, program pengayaan, layanan konseling dan/atau memberikan tugas 
baik tugas individual maupun kelompok sesuai dengan hasil belajar peserta didik; dan (5) menyampaikan rencana pembelajaran pada pertemuan berikutnya.

Ada beberapa hal yang perlu diperhatikan agar internalisasi nilai-nilai terjadi dengan lebih intensif selama tahap penutup.

1) Selain simpulan yang terkait dengan aspek pengetahuan, agar peserta didik difasilitasi membuat pelajaran moral yang berharga yang dipetik dari pengetahuan/keterampilan dan/atau proses pembelajaran yang telah dilaluinya untuk memperoleh pengetahuan dan/atau keterampilan pada pelajaran tersebut.

2) Penilaian tidak hanya mengukur pencapaian siswa dalam pengetahuan dan keterampilan, tetapi juga pada perkembangan karakter mereka.

3) Umpan balik baik yang terkait dengan produk maupun proses, harus menyangkut baik kompetensi maupun karakter, dan dimulai dengan aspek-aspek positif yang ditunjukkan oleh siswa.

4) Karya-karya siswa dipajang untuk mengembangkan sikap saling menghargai karya orang lain dan rasa percaya diri.

5) Kegiatan tindak lanjut dalam bentuk pembelajaran remedi, program pengayaan, layanan konseling dan/atau memberikan tugas baik tugas individual maupun kelompok diberikan dalam rangka tidak hanya terkait dengan pengembangan kemampuan intelektual, tetapi juga kepribadian.

6) Berdoa pada akhir pelajaran.

Setelah guru menganggap kegiatan akhir selesai dilaksanakan secara optimal dan sesuai dengan waktu yang direncanakan, maka langkah selanjutnya guru harus menutup pelajaran. Apabila jam pelajarannya yang paling akhir, maka harus dibiasakan siswa menutup dengan berdoa. Selain faktor dia atas untuk mewujudkan proses pembelajaran karakter disiplin anak, masih ada beberapa faktor lain yang mempengaruhi proses pendidikan karakter disiplin anak, yaitu:

1. Guru harus merupakan seorang model dalam karakter disiplin, dari awal hingga akhir pelajaran, tutur kata, sikap, dan perbuatan guru harus merupakan cerminan dari nilai-nilai karakter yang hendak ditanamkannya.

2. Guru harus memberikan reward kepada siswa yang menunjukkan karakter disiplin yang dikehendaki dan pemberian punishment kepada mereka yang berperilaku dengan karakter 
yang tidak dikehendaki. Reward dan punishment yang dimaksud dapat berupa ungkapan verbal dan non verbal, kartu ucapan selamat (misalnya classroom award) atau catatan peringatan, dan sebagainya. Untuk itu guru harus menjadi pengamat yang baik bagi setiap siswanya selama proses pembelajaran.

3. Hindari mengolok-olok siswa yang datang terlambat atau menjawab pertanyaan dan/atau berpendapat kurang tepat/relevan. Pada sejumlah sekolah ada kebiasaan diucapkan ungkapan Hoo,,, oleh siswa secara serempak saat ada teman mereka yang terlambat dan/atau menjawab pertanyaan atau bergagasan kurang berterima. Kebiasaan tersebut harus dijauhi untuk menumbuhkembangkan sikap bertanggung jawab, empati, kritis, kreatif, inovatif, rasa percaya diri, dan sebagainya.

4. Guru memberi umpan balik dan/atau penilaian kepada siswa, guru harus mulai dari aspekaspek positif atau sisi-sisi yang telah kuat/baik pada pendapat, karya, dan/atau sikap siswa.

5. Guru menunjukkan kekurangan-kekurangannya dengan 'hati'. Dengan cara ini sikap-sikap saling menghargai dan menghormati, kritis, kreatif, percaya diri, santun, terutama pada aspek Kedisiplinan dan sebagainya akan tumbuh subur.

\section{Strategi Guru dalam Menerapkan Pendidikan Karakter Disiplin Anak}

Ada beberapa strategi yang dapat memberikan peluang dan kesempatan bagi guru untuk memainkan peranannya secara optimal dalam hal pengembangan pendidikan karakter disiplin peserta didik di sekolah, sebagai berikut :

1. Optimalisasi peran guru dalam proses pembelajaran. Guru tidak seharusnya menempatkan diri sebagai aktor yang dilihat dan didengar oleh peserta didik, tetapi guru seyogyanya berperan sebagai sutradara yang mengarahkan, membimbing, memfasilitasi dalam proses pembelajaran, sehingga peserta didik dapat melakukan dan menemukan sendiri hasil belajarnya.

2. Integrasi materi pendidikan karakter ke dalam mata pelajaran. Guru dituntut untuk peduli, mau dan mampu mengaitkan konsep-konsep pendidikan karakter pada materi-materi pembelajaran dalam mata pelajaran yang diampunya. Dalam hubungannya dengan ini, setiap guru dituntut untuk terus menambah wawasan ilmu pengetahuan yang berkaitan dengan pendidikan karakter, yang dapat diintegrasikan dalam proses pembelajaran.

3. Mengoptimalkan kegiatan pembiasaan diri yang berwawasan pengembangan budi pekerti dan akhlak mulia. Para guru (pembina program) melalui program pembiasaan diri lebih 
mengedepankan atau menekankan kepada kegiatan-kegiatan pengembangan budi pekerti dan akhlak mulia yang kontekstual, kegiatan yang menjurus pada pengembangan kemampuan afektif dan psikomotorik.

4. Penciptaan lingkungan sekolah yang kondusif untuk tumbuh dan berkembangnya karakter disiplin peserta didik. Lingkungan terbukti sangat berperan penting dalam pembentukan pribadi manusia (peserta didik), baik lingkungan fisik maupun lingkungan spiritual. Untuk itu sekolah dan guru perlu untuk menyiapkan fasilitas-fasilitas dan melaksanakan berbagai jenis kegiatan yang mendukung kegiatan pengembangan pendidikan karakter peserta didik.

5. Menjalin kerjasama dengan orang tua peserta didik dan masyarakat dalam pengembangan pendidikan karakter. Bentuk kerjasama yang bisa dilakukan adalah menempatkan orang tua peserta didik dan masyarakat sebagai fasilitator dan nara sumber dalam kegiatan-kegiatan pengembangan pendidikan karakter yang dilaksanakan di sekolah.

6. Menjadi figur teladan bagi peserta didik. Penerimaan peserta didik terhadap materi pembelajaran yang diberikan oleh seorang guru, sedikit tidak akan bergantung kepada penerimaan pribadi peserta didik tersebut terhadap pribadi seorang guru. Ini suatu hal yang sangat manusiawi, dimana seseorang akan selalu berusaha untuk meniru, mencontoh apa yang disenangi dari model/figurnya tersebut. Momen seperti ini sebenarnya merupakan kesempatan bagi seorang guru, baik secara langsung maupun tidak langsung menanamkan nilai-nilai karakter dalam diri pribadi peserta didik. Dalam proses pembelajaran, integrasi nilai-nilai karakter tidak hanya dapat diintegrasikan ke dalam subtansi atau materi pelajaran, tetapi juga pada prosesnya

Uraian diatas menggambarkan peranan guru dalam proses pendidikan karakter di sekolah yang berkedudukan sebagai katalisator atau teladan, inspirator, motivator, dinamisator, dan evaluator. Dalam berperan sebagai katalisator, maka keteladanan seorang guru merupakan faktor mutlak dalam pengembangan pendidikan karakter peserta didik yang efektif, karena kedudukannya sebagai figur atau idola yang ditiru oleh peserta didik. Peran sebagai inspirator berarti seorang guru harus mampu membangkitkan semangat peserta didik untuk maju mengembangkan potensinya.

Peran sebagai motivator, mengandung makna bahwa setiap guru harus mampu membangkitkan spirit, etos kerja dan potensi yang luar biasa pada diri peserta didik. Peran sebagai dinamisator, bermakna setiap guru memiliki kemampuan untuk mendorong peserta didik 
ke arah pencapaian tujuan dengan penuh kearifan, kesabaran, cekatan, cerdas dan menjunjung tinggi spiritualitas. Sedangkan peran guru sebagai evaluator, berarti setiap guru dituntut untuk mampu dan selalu mengpenilaian sikap atau prilaku diri, dan metode pembelajaran yang dipakai dalam pengembangan pendidikan karakter peserta didik, sehingga dapat diketahui tingkat efektivitas, efisiensi, dan produktivitas programnya.

\section{Penilaian yang Dilakukan Oleh Guru dalam Menilai Keberhasilan Pendidikan Karakter Disiplin Anak.}

Penilaian dalam pendidikan karakter disiplin adalah melakukan penilaian terhadap proses kegiatan belajar dan penilaian hasil kegiatan. Penilaian dilakukan secara observasi dan pengamatan terhadap cara belajar anak baik individual atau kelompok. Tujuan penilaian ini dilakukan untuk mengetahui sejauh mana perkembangan yang dicapai oleh anak sesuai tujuan yang sudah direncanakan.

Secara menyeluruh program penilaian bertujuan mengetahui semua peserta didik yang sudah mampu dan yang kurang mampu dalam penerapan pembelajaran tersebut. Tujuan penilaian bukan hanya anak didik saja, tetapi juga bertujuan penilaian pendidik, yaitu sejauh mana pendidik bersungguh-sungguh dalam menjalankan tugasnya untuk mencapai tujuan pendidikan Islam. Ada beberapa prinsip yang harus diperhatikan dalam penilaian pendidikan Islam, yaitu: prinsip kontinuitas, prinsip menyeluruh, prinsip objektivitas, dan prinsip mengacu pada tujuan. Dalam implementasi penilaian dalam pendidikan karakter memang tidak semudah membalik tangan, namun itu semua adalah tantangan bagi dunia pendidikan sekarang dan masa mendatang. (Dirjen PMPTK Depdiknas, 2008:3).

Selain penilaian untuk pendidik dan tenaga kependidikan, penilaian pencapaian nilai-nilai budaya dan karakter juga dapat ditujukan kepada peserta didik yang didasarkan pada beberapa indikator. Sebagai contoh, indikator untuk nilai disiplin disatu semester dirumuskan dengan "menunjukkan disiplin dalam menaati peraturan yaitu masuk sekolah sesuai jadwal yang sudah ditentukan" maka pendidik mengamati (melalui berbagai cara) apakah yang dilakukan seorang peserta didik itu sudah sesuai dengan apa yang ditentukan.

Penilaian pendidikan karakter disiplin anak dilakukan secara terus menerus, setiap saat guru berada di kelas atau di sekolah. Model anecdotal record (catatan yang dibuat guru ketika melihat adanya perilaku yang berkenaan dengan nilai yang dikembangkan) selalu dapat digunakan guru. Selain itu, guru dapat pula memberikan tugas yang berisikan suatu persoalan 
atau kejadian yang memberikan kesempatan kepada peserta didik untuk menunjukkan nilai yang dimilikinya. Sebagai contoh, peserta didik dimintakan bersikapnya tertib ketika proses pembelajaran akan dimulai, atau hal-hal lain yang bersifat bukan kontroversial sampai kepada hal yang dapat mengundang konflik pada dirinya.

Dari hasil pengamatan, catatan anecdot, tugas, laporan, dan sebagainya pendidik dapat memberikan kesimpulan/pertimbangan tentang pencapaian suatu indikator atau bahkan suatu nilai. Kesimpulan/pertimbangan tersebut dapat dinyatakan dalam pernyataan kualitatif dan memiliki makna terjadinya proses pembangunan karakter sebagai berikut ini.

Dalam penilaian pendidikan karakter idealnya menggunakan yang sudah disarankan oleh Kemendiknas tentang pengembangan pendidikan budaya dan karakter bangsa 2010 yang menjelaskan tentang bagaimana penilaian mengenai pendidikan karakter. Berikut adalah contoh penilaian pendidikan karakter yang seharusnya dijalankan oleh sekolah:

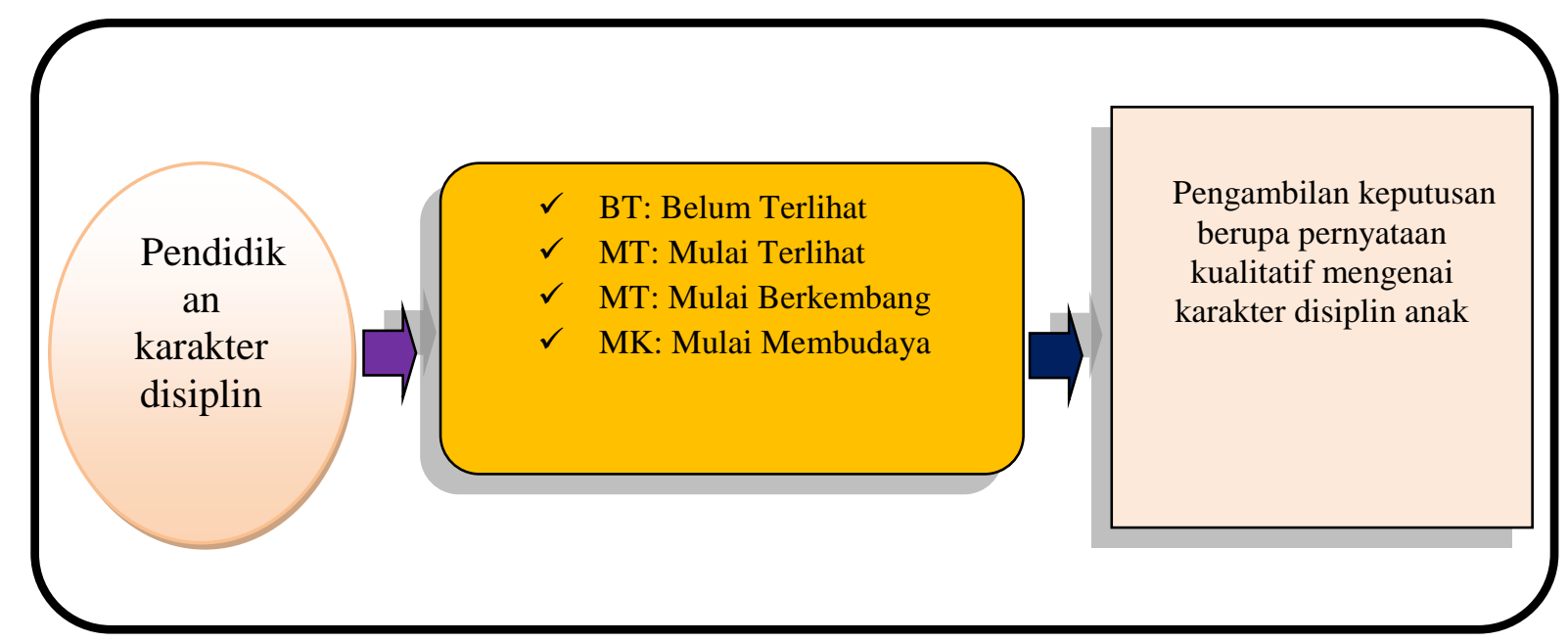

Gambar. Skema Penilaian Pendidikan Karakter Disiplin

BT: Belum Terlihat, apabila peserta didik belum memperlihatkan tanda- tanda awal perilaku yang dinyatakan dalam indikator karena belum memahami makna dari nilai itu (Tahap Anomi).

MT: Mulai Terlihat, apabila peserta didik sudah mulai memperlihatkan adanya tanda-tanda awal perilaku yang dinyatakan dalam indikator tetapi belum konsisten karena sudah ada pemahaman dan mendapat penguatan lingkungan terdekat (Tahap Heteronomi).

MB: Mulai Berkembang, apabila peserta didik sudah memperlihatkan berbagai tanda perilaku yang dinyatakan dalam indikator dan mulai konsisten, karena selain sudah ada pemahaman dan 
kesadaran juga mendapat penguatan lingkungan terdekat dan lingkungan yang lebih luas (Tahap Sosionomi).

MK: Membudaya, apabila peserta didik terus menerus memperlihatkan perilaku yang dinyatakan dalam indikator secara konsisten karena selain sudah ada pemahaman dan kesadaran dan mendapat penguatan lingkungan terdekat dan lingkungan yang lebih luas sudah tumbuh kematangan moral (Tahap Autonomi).

Pernyataan kualitatif di atas dapat digunakan ketika guru melakukan asesment pada setiap kegiatan belajar sehingga guru memperoleh profile peserta didik dalam satu semester tentang nilai terkait (kedisiplinan dan sebagainya). Guru dapat pula menggunakan BT, MT, MB atau MK tersebut dalam penilaian.

\section{Sasaran Penilaian dalam Pendidikan Karakter Disiplin Anak Usia Dini.}

Langkah yang harus ditempuh seorang pendidik dalam memberi penilaian adalah menetapkan apa yang menjadi sasaran penilaian tersebut. Sasaran penilaian sangat penting untuk diketahui supaya memudahkan pendidik dalam menyusun alat-alat penilaiannya. Pada umumnya ada tiga sasaran pokok penilaian dalam pendidikan karakter yaitu: (1) Segi tingkah laku, artinya segi-segi yang menyangkut sikap, minat, perhatian, keterampilan peserta didik sebagai akibat dari proses belajar mengajar (2) Segi pengetahuan, artinya penguasaan pelajaran yang diberikan oleh guru dalam proses belajar mengajar (3) Segi yang menyangkut proses belajar mengajar yaitu bahwa proses belajar mengajar perlu diberi penilaian secara obyektif dari guru. Sebab baik tidaknya proses belajar mengajar akan menentukan baik tidaknya hasil belajar yang dicapai oleh peserta didik.

\section{Faktor Pendukung dan Penghambat Pendidikan Karakter Disiplin Anak}

a. Faktor Pendukung Pendidikan Karakter Disiplin Anak

Faktor pendorong kedisiplinan dalam sebuah lembaga pendidikan merupakan suatu faktor yang menunjang dalam melaksanakan aturan dalam menjalankan kedisiplinan pada sebuah lembaga pendidikan”. Faktor ini merupakan faktor yang sangat penting dan urgen yang harus terus menerus dilaksanakan. Apabila faktor pendorong atau faktor pendukung kedisiplinan sudah mendukung maka kedisiplinan di sekolah akan dapat berjalan sebagaimana diinginkan. patuhan dapat melemah.

Faktor yang berpengaruh pada pembentukan karakter disiplin anak, yaitu: (1) Teladan, Perbuatan dan tindakan kerap kali lebih besar pengaruhnya dibandingkan dengan kata-kata. 
Dalam hal ini siswa lebih mudah meniru apa yang mereka lihat (dianggap baik dan patut ditiru) daripada dengan apa yang mereka dengar. Lagi pula, hidup manusia banyak dipengaruhi peniruan-peniruan terhadap apa yang dianggap baik dan patut ditiru. (2) Lingkungan berdisiplin, Lingkungan sangat besar pengaruhnya. Apabila berada dilingkungan yang berdisiplin, seseorang dapat terbawa oleh lingkungan tersebut. Hal ini menunjukkan bahwa manusia mampu beradaptasi dengan lingkungannya sehingga dapat mempertahankan hidupnya (3) Latihan berdisiplin. Disiplin dapat dicapai dan dibentuk melalui proses latihan dan kebiasaan, artinya dengan melakukan disiplin secara berulang-ulang dan membiasakannya dalam praktik disiplin sehari-hari yang menjadi suatu kebiasaan yang tidak dapat ditinggalkan. Dengan latihan dan membiasakan diri, disiplin tidak akan menjadi suatu beban yang dirasa sangat memberatkan bagi siswa terutama dalam melaksanakan segala kegiatan yang berhubungan dengan belajar (Tulus Tu`u, 2004: 49).

\section{b. Faktor Penghambat Pendidikan Karakter Disiplin Anak}

Pelaksanaan pembelajaran karakter disiplin anak tidak lepas dari kendala atau faktor penghambat yang harus dihadapi. Adapun faktor yang menjadi penghambat dalam pendidikan karakter disiplin anak di antaranya: (1) Disiplin sekolah yang kurang direncanakan dengan baik. (2) Perencanaan yang baik, tetapi implementasinya kurang baik dan kurang dimonitor oleh kepala sekolah (3) Penerapan disiplin yang tidak konsisten dan tidak konsekuen. (4) Kebijakan kepala sekolah yang belum memprioritaskan peningkatan dan pemantapan disiplin sekolah. (5) Kurang kerjasama dan dukungan guru-guru dalam perencanaan dan implementasi disiplin sekolah. (6) Kurangnya dukungan dan partisipasi orang tua dalam menangani disiplin sekolah, secara khusus siswa yang bermasalah. (7) Kurangnya tenaga guru yang ikut dalam pengawasan kegiatan tersebut sehingga kegiatan tersebut menjadi kurang tertib.

\section{SIMPULAN}

Penelitian yang dilakukan di Al-Muna Islamic Preschool yang berfokus pada pendidikan karakter disiplin pada anak usia dini memberikan simpulan sebagai berikut:

1. Perencanaan pendidikan karakter disiplin anak di Al-Muna Islamic Preschool disesuaikan dengan tema yang akan di bahas, agar tercipta sebuah kesatuan pembelajaran yang integral atau tidak terputus. Perencanaan pembelajaran sebagai pedoman awal dalam menyelenggarakan kegiatan pembelajaran sehingga tujuan pendidikan dapat tercapai. Perencanaan pembelajaran merupakan suatu rangkaian yang saling berhubungan dan saling 
menunjang antara keseluruhan komponen di dalam pembelajaran. Peran guru dalam perencanaan pendidikan karakter adalah mempersiapkan media yang berhubungan dengan perkembangan sikap dan perilaku atau sosial emosi anak. Sebelum melakukan proses pembelajaran, guru membuat pemetaan, silabus, program tahunan, program semester, program mingguan, dan program harian yang di dalamnya sudah tercantum mengenai tujuan, bahan ajar, alokasi waktu, media, strateginya, dan penilaian.

2. Proses pendidikan karakter disiplin anak dilaksanakan dengan sistem sentra agar apa yang telah direncanakan lebih terarah dan tepat sasaran. Anak diharapkan memiliki karakter disiplin melalui tiga hal yaitu dengan cara knowing, feeling, dan acting. Knowing melalui bercerita dapat menanamkan nilai-nilai kedisiplinan dan berwawasan. Feeling bertujuan untuk menggugah perasaan anak atau menumbuhkan empaty anak. Acting, yaitu praktek secara langsung pada sasarannya.

3. Penilaian pendidikan karakter disiplin anak dapat dilihat dalam perkembangan dan perubahan sikap dan perilaku anak sehari-hari yang tercatat dalam lembar observasi, catatan harian dan catatan anekdot.

4. Faktor pendukung dalam penerapan pendidikan karakter disiplin anak usia dini yaitu, faktor dorongan dari dalam dan dorongan dari luar. Dorongan dari dalam meliputi; pengalaman seorang guru dalam pelaksanaan pembelajaran di sekolah, Pengikutan dan ketaatan merupakan langkah penerapan dan praktik atas peraturan yang mengatur perilaku individu (disiplin), Sarana Pendidikan, kesadaran, kemauan untuk berdisiplin. Sedangkan dorongan dari luar meliputi: peraturan yang ada, pengawasan, paksaan yang konstruktif dan hukuman untuk berdisiplin. Selain faktor itu juga ada faktor lain yang mendorong dalam penerapan pendidikan karakter disiplin anak yang meliputi; teladan yang baik, lingkungan berdisiplin, latihan berdisiplin.

Sedangkan faktor penghambat dalam penerapan pendidikan karakter disiplin anak usia dini yaitu; Pertama disiplin sekolah yang kurang direncanakan dengan baik, kedua Perencanaan yang baik, tetapi implementasinya kurang baik dan kurang dimonitor oleh kepala sekolah. ketiga Penerapan disiplin yang tidak konsisten dan tidak konsekuen. Keempat kebijakan kepala sekolah yang belum memprioritaskan peningkatan dan pemantapan disiplin sekolah. Kelima Kurang kerjasama dan dukungan guru-guru dalam perencanaan dan implementasi disiplin sekolah. Keenam Kurangnya dukungan dan partisipasi orang tua dalam menangani disiplin sekolah, 
secara khusus siswa yang bermasalah. Ketujuh Kurangnya tenaga guru yang ikut dalam pengawasan kegiatan tersebut sehingga kegiatan tersebut menjadi kurang tertib.

\section{DAFTAR PUSTAKA}

Agboola, A. 2012. Bring Character Education into Classroom, European Journal Of Educational Research University of the Incarnate Word. Vol. 1, No. 2, Page. 163-170.

Arikunto, S. 1992. Prosedur Penelitian Suatu Pendekatan Praktek. Jakarta: Rineka Cipta.

Arikunto, S. 2008. Prosedur Penelitian Suatu Pendekatan Praktik. Jakarta: PT. Asdi Mahasatya.

Berkowitz, M.W. 2011. The Science Of Caracter Education, Jurnal Internasional Hoover press: Damon. Page 46-53.

Berkson, W.J. 2003. Psikologi Belajar dan Filsafat Ilmu Karl Popper. Terjemahan oleh Ali Noer Zaman. Yogyakarta: Qalam.

Depdiknas. 2006. Permendiknas No. 22 Tahun 2006. Jakarta: Depdiknas.

Djamarah, S. 2002. Rahasia Sukses Belajar. Jakarta: PT Asdi Mahasatya.

Fihris, S. 2010. Pendidikan Karakter di Madrasah Salafiyah Semarang. IAIN Walisongo Semarang.

Haling, M.T. 2012. The Development of Character Education Curriculum For Elementary School Students. International Journal on Social Science Universiti Kebangsaan Malaysia.Vol.2. Page. 8-11.

Hasan, M. 2010. Pendidikan Anak Usia Dini, Jogjakarta: DIVA Press.

Jamaluddin. 2013. Character Education in Islamic Perspective , International Journal Of Scientific \& Technology Research.Vol.2,Page, 187-189.

Kemendiknas. 2010. Pendidikan Karakter Terintegrasi dalam Pembelajaran di Sekolah Menengah Pertama. Jakarta: Kemdiknas.

Kohn, A. 1997. How Not To Teach Values; A critical Look at Character Education, Jurnal Internasional, Phi Delta Kappan. Vol. 3. Page. 1-8.

Mardalis. 2004. Metode Penelitian Suatu Pendekatan Proposal. Jakarta: Bumi Aksara.

Megawangi, R. 2004. Pendidikan Karakter: Solusi Tepat untuk Membangun Bangsa. Depok: Indonesia Heritage Foundation.

Miles, B.B., dan A.M. Huberman, 1992, Analisa Data Kualitatif. Jakarta: UI Press.

Munandar, U, 2009. Pengembangan Kreativitas Anak Berbakat. Jakarta: PT Rineka Cipta.

Mursid. 2009. Kurikulum dan pendidikan Anak Usia Dini. Semarang: Akfi Media.

Masnur, M. 2011. Pendidikan Karakter Menjawab Tantangan Krisis Multidimensional. Jakarta: Bumi Aksara.

Muslich, M. 2011. Pendidikan Karakter Menjawab Tantangan Krisis Multidimensional. Jakarta: Bumi Aksara.

Pusat Kurikulum. 2009. Pengembangan dan Pendidikan Budaya \& Karakter Bangsa. Depdiknas.

Sagala, S. 2010. Konsep dan Makna Pembelajaran; Untuk Membantu Memecahkan Problematika Belajar dan Mengajar. Bandung : Al Fabeta. 
Sagala, S, 2010. Manajemen Strategik Dalam Peningkatan Mutu Pendidikan. Bandung: Alfabeta.

Sanjaya, Wina, 2005, Pembelajaran dalam Implementasi Kurikulum Berbasis Kompetensi, Edisi Pertama Cetakan Kedua, Kencana Prenada Group, Jakarta.

Sulhan, N. 2010. Pendidikan Berbasis Karakter. Surabaya: PT JePe Press Media Utama. Sugiyono. 2008. Memahami Penelitian Kualitatif. Bandung: CV Alfabeta.

Tulus, T, 2004. Peran Disiplin pada Perilaku dan Prestasi Siswa. Jakarta:PT. Grasindo. 